\title{
Assessment of Historical and Current Distribution Records of the Indo- Pacific Slender Gecko, Hemiphyllodactylus typus Bleeker, 1860, in Sri Lanka
}

\author{
Hareschandra Bandula Jayaneththi ${ }^{1, *}$ and Daniel Jablonski ${ }^{2}$ \\ ${ }^{1}$ Young Zoologists' Association of Sri Lanka, National Zoological Garden, Dehiwala, Sri Lanka \\ ${ }^{2}$ Department of Zoology, Comenius University in Bratislava, Mlynská dolina, Ilkovičova 6, 84215 Bratislava, \\ Slovakia
}

\begin{abstract}
Hemiphyllodactylus typus is a widespread but low abundant parthenogenetic taxon, which is widely distributed through Southeast Asia and the entire tropical Pacific Ocean of New Guinea to some other Oceanic Islands. The present study has reviewed the data from a combination of literature together with our unpublished field records. A total of 36 localities of $H$. typus were detected, including four recent observations or repeated observations. Some information regarding the natural history, autecology and biogeography of $H$. typus in Sri Lanka are given.
\end{abstract}

Keywords: parthenogenetic species, new records, syntopic occurrence, allochtony, human-mediated introduction.

\section{INTRODUCTION}

Hemiphyllodactylus typus is a widespread, unisexual (parthenogenetic) species and thus the populations comprise only of females with developed precloacal and femoral pores. This species is distributed through Southeast Asia and the entire tropical Pacific Ocean west of New Guinea to the Sunda Islands and eastward towards the islands and atolls of eastern Polynesia reaching Pitcairn Island. The species has probably been introduced into the Philippines, Taiwan, Andaman and Nicobar (India) and Mascarene Islands, Ryukyu and Iriomotejima Islands (Japan), New Caledonia (questionable) and Hawaiian Islands in the USA (Das, 1999; Lever, 2003; Zug, 2010; Chandramouli et al., 2012; Fisher et al., 2013; Holden et al., 2014). Its apparent scarcity is certainly related to its small size, strictly nocturnal mode of life, and secretive behaviour (Zug, 2010).
Batuwita \& Alagiyawadu (2004) presented that individuals from coastal zones are more or less slender bodied while those from the central hills are robust. However, populations of Hemiphyllodactylus from Sri Lanka are also possibly formed by bisexual populations, which is not examined so far (see Somaweera \& Somaweera, 2009; Zug, 2010). H. typus is considered as an endangered species in Sri Lanka, The Red-List criterion has amended in 2012 under the 'Nationally Vulnerable' B1 ab (ii) (MENR, 2012).

\section{MATERIAL AND METHODS}

This article provides a combination of information from published literature together with our unpublished field records. This is necessary in view of insularity of the study region, exceptionally high species diversity of reptiles, probable presence of both unisexual and bisexual populations of Hemiphyllodactylus and the possibility of its introductions through accidental human transport.

All records were georeferenced. However, coordinates of some historical records correspond to the closest village/regions nearby and do not represent the exact sites of the recorded finding. Based on obtained coordinates (see Table 1) we generated a distribution map for H. typus in Sri Lanka using DIVA-GIS 7.5 (Hijmans et al., 2012). The records were divided into two categories, already published and our new records. Field observations of $H$. typus were encountered during three regular field visits and one random spot between 2004 and 2015 (Table 1). Visual spotting on habitats with occasional hand capture was done during the diurnal and 
nocturnal observations. Some measurements were taken with a digital vernier scale (Mannesmann Electronic Precision/0-150 mm). Specimens were identified following Smith (1935), Deraniyagala (1953), Somaweera \& Somaweera (2009) and Zug (2010). No voucher specimens were collected.

\section{RESULTS}

A total of 36 localities of $H$. typus were detected including four recent observations (see Table 1 and Figure 1). All observation sites were from wet and intermediate zones of the island and the locations were confined to lowland, sub-montane or montane and moist monsoon forests (see Table 1; cf. Somaweera \& Somaweera, 2009). Habitats of recent sightings are described below. All observed specimens were females.

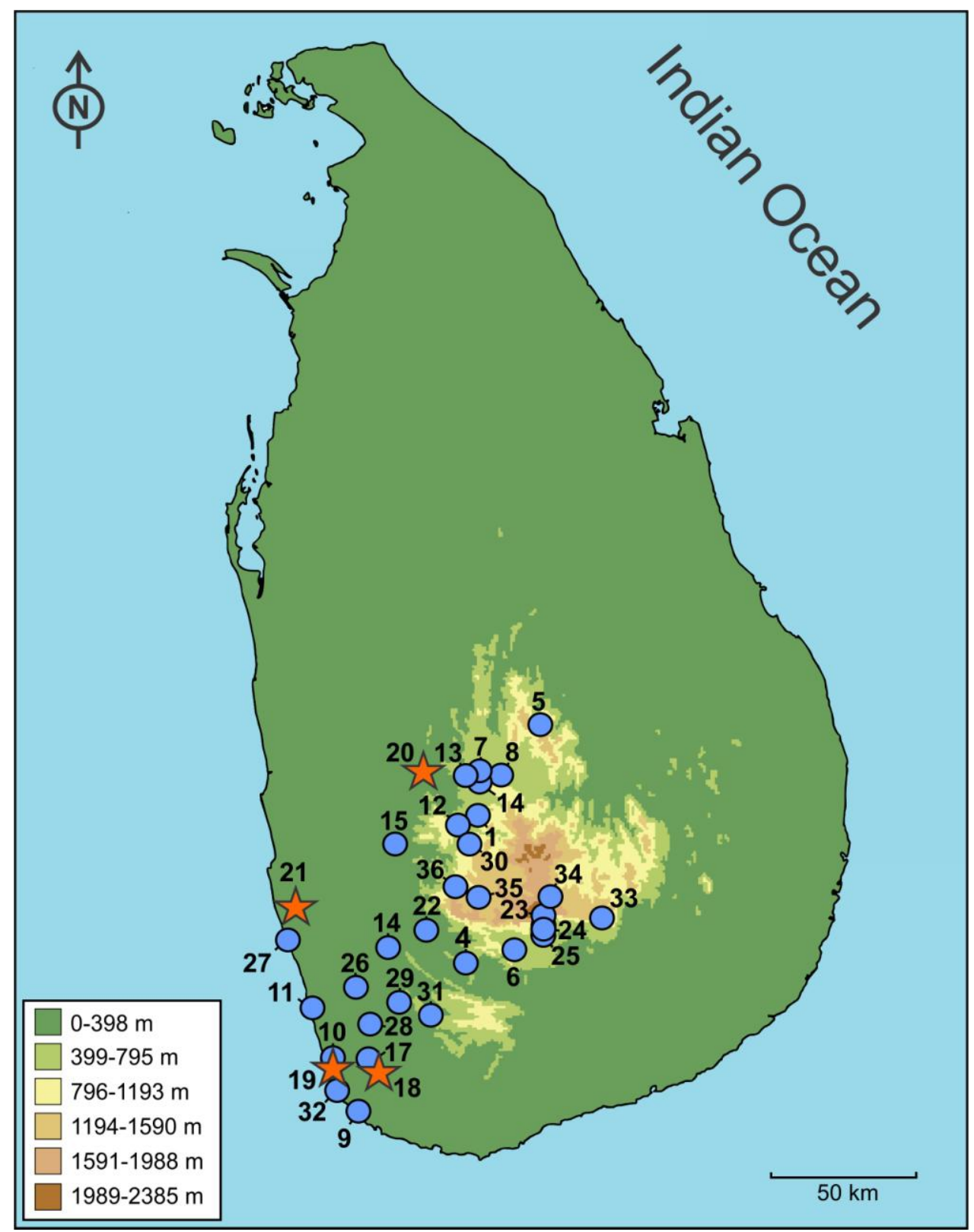

Figure 1: Updated distribution map of Hemiphyllodactylus typus in Sri Lanka based on published (blue spots) and new records in the present study (orange stars). See Table 1 for other details. 
Table 1. Distribution sites and descriptions of published records including new localities of Hemiphyllodactylus typus in Sri Lanka.

\begin{tabular}{|c|c|c|c|c|c|c|c|}
\hline No. & Location & District & Habitat \& notes & Latitude (N) & Longitude (E) & Altitude (m) & Source/s \\
\hline 1 & Gampola & Kandy & $\begin{array}{l}\text { First record in Sri Lanka/ } \\
\text { Beddome Collection }\end{array}$ & $7^{\circ} 7^{\prime} 28.15^{\prime \prime}$ & $80^{\circ} 34^{\prime} 44.86^{\prime \prime}$ & 595 & Boulenger 1885,1890 \\
\hline 2 & Ceylon & not given & Deraniyagala's collection & Not available & Not available & & Smith, 1935 \\
\hline 3 & Ceylon & not given & Probably equal to Site No. 2 & Not available & Not available & & Daraniyagala, 1953 (in 1932) \\
\hline 4 & Palmadulla & Rathnapura & Location not specified & $6^{\circ} 38^{\prime} 4.14^{\prime \prime}$ & $80^{\circ} 31^{\prime} 47.83^{\prime \prime}$ & 150 & Deraniyagala, 1953 \\
\hline 5 & $\begin{array}{l}\text { Kalupahana } \\
\text { Knuckles Range }\end{array}$ & Matale & Location not specified & $7^{\circ} 26 \prime 28.58^{\prime \prime}$ & $80^{\circ} 47^{\prime} 48.85^{\prime \prime}$ & $\sim 1200$ & $\begin{array}{l}\text { Ginige, 1994, cited in } \\
\text { Goonewardene et al., 2006, } \\
\text { p.82; and De Silva et } \text { al., } 2005\end{array}$ \\
\hline 6 & Balangoda & Ratnapura & Location not specified & $6^{\circ} 39^{\prime} 15.82^{\prime \prime}$ & $80^{\circ} 41^{\prime} 54.41^{\prime \prime}$ & 547 & $\begin{array}{l}\text { Deraniyagala, } 1953 \text { (observation } \\
\text { made in 1940) } \\
\text { Manamendra-Arachchi, } 1997\end{array}$ \\
\hline 7 & Gannoruwa & Kandy & Human settlements & $7^{\circ} 16^{\prime} 48.56^{\prime \prime}$ & $80^{\circ} 35^{\prime} 28.21^{\prime \prime}$ & 473 & Batuwita, 2000 \\
\hline 8 & $\begin{array}{ll}\text { Ampitiya } & \text { (near } \\
\text { Dodanwela) } & \\
\end{array}$ & Kandy & Home garden & $7^{\circ} 15 ' 55.84^{\prime \prime}$ & $80^{\circ} 39^{\prime} 39.50^{\prime \prime}$ & 565 & Somaweera et al., 2001 \\
\hline 9 & $\begin{array}{l}\text { Pitiwela } \quad \text { (near } \\
\text { Boossa) }\end{array}$ & Galle & Location not specified & $6^{\circ} 5^{\prime} 15.81^{\prime \prime}$ & $80^{\circ} 9^{\prime} 43.63 "$ & 18 & $\begin{array}{l}\text { Batuwita \& Alagiyawadu, 2004; } \\
\text { Batuwita \& Bahir, 2005; } \\
\text { Manamendra-Arachchi et al., } \\
2007\end{array}$ \\
\hline 10 & $\begin{array}{l}\text { Polwatta (near } \\
\text { Ambalangoda) }\end{array}$ & Galle & Location not specified & $6^{\circ} 15^{\prime} 40.12^{\prime \prime}$ & $80^{\circ} 4^{\prime} 0.08^{\prime \prime}$ & 13 & Batuwita \& Alagiyawadu, 2004 \\
\hline 11 & Aluthgama & Kalutara & Location not specified & $6^{\circ} 26 ' 58.97 "$ & $80^{\circ} 0^{\prime} 1.20^{\prime \prime}$ & 13 & Batuwita \& Alagiyawadu, 2004 \\
\hline 12 & Pussellawa & Kandy & Location not specified & $7^{\circ} 5^{\prime} 39.54 "$ & $80^{\circ} 30^{\prime} 17.67^{\prime \prime}$ & 734 & Batuwita \& Alagiyawadu, 2004 \\
\hline 13 & Pilimathalawa & Kandy & Location not specified & $7^{\circ} 15^{\prime} 52.15^{\prime \prime}$ & $80^{\circ} 32^{\prime} 10.65^{\prime \prime}$ & 512 & Batuwita \& Alagiyawadu, 2004 \\
\hline 14 & Penideniya & Kandy & Location not specified & $7^{\circ} 15^{\prime} 10.73^{\prime \prime}$ & $80^{\circ} 35^{\prime} 20.97^{\prime \prime}$ & 507 & Batuwita \& Alagiyawadu, 2004 \\
\hline 15 & Kegalle & Kegalle & Location not specified & $7^{\circ} 15^{\prime} 4.79^{\prime \prime}$ & $80^{\circ} 20^{\prime} 46.95^{\prime \prime}$ & 227 & Somaweera \& Somaweera, 2009 \\
\hline 16 & Kukulugala & $\begin{array}{l}\text { Ratnapura } \\
\text { Kalutara }\end{array}$ & Secondary forest & $6^{\circ} 39^{\prime} 41.81^{\prime \prime}$ & $80^{\circ} 15^{\prime} 41.41^{\prime \prime}$ & 485 & $\begin{array}{l}\text { Karunarathna \& Amarasinghe, } \\
\text { 2010; Karunarathna et al., } 2015\end{array}$ \\
\hline 17 & $\begin{array}{l}\text { Beraliya-Mukalana } \\
\text { (near Elpitiya) }\end{array}$ & Galle & $\begin{array}{l}\text { Primary montane forest (near } \\
\text { Elpitiya) }\end{array}$ & $6^{\circ} 16^{\prime 20.09 "}$ & $80^{\circ} 11^{\prime} 48.16^{\prime \prime}$ & 134 & $\begin{array}{l}\text { Karunarathna \& Amarasinghe, } \\
\text { 2012; Karunarathna et al., } 2015\end{array}$ \\
\hline
\end{tabular}




\begin{tabular}{|c|c|c|c|c|c|c|c|}
\hline No. & Location & District & Habitat \& notes & Latitude $(\mathbf{N})$ & Longitude (E) & Altitude (m) & Source/s \\
\hline 18 & $\begin{array}{l}\text { Morankanda } \\
\text { Mukalana }\end{array}$ & Galle & $\begin{array}{l}\text { Tea plantation with rocky } \\
\text { scrub and anthropogenic } \\
\text { features }\end{array}$ & $6^{\circ} 13^{\prime} 16.39^{\prime \prime}$ & $80^{\circ} 14^{\prime} 0.17^{\prime \prime}$ & 54 & $\begin{array}{l}\text { Jayaneththi, 2015; Jayaneththi et } \\
\text { al., 2015; This study }\end{array}$ \\
\hline 19 & $\begin{array}{l}\text { Godahena (near } \\
\text { Ambalangoda) }\end{array}$ & Galle & $\begin{array}{l}\text { Mangrove forest in Madampa } \\
\text { Lake with manmade building; } \\
\text { anthropogenic habitat }\end{array}$ & $6^{\circ} 14^{\prime} 6.94^{\prime \prime}$ & $80^{\circ} 4^{\prime} 18.22^{\prime \prime}$ & 11 & $\begin{array}{l}\text { Jayaneththi et al., 2015; This } \\
\text { study }\end{array}$ \\
\hline 20 & Pinnawala & Kegalle & anthropogenic habitat & $7^{\circ} 18^{\prime} 3.34^{\prime \prime}$ & $80^{\circ} 23^{\prime} 26.20^{\prime \prime}$ & 96 & Present study \\
\hline 21 & Kasbewa & Colombo & 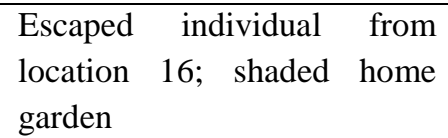 & $6^{\circ} 48^{\prime} 2.83^{\prime \prime}$ & $79^{\circ} 56^{\prime 29.64 "}$ & 22 & Present study \\
\hline 22 & Ratnapura & Ratnapura & & $6^{\circ} 42^{\prime} 26.17^{\prime \prime}$ & $80^{\circ} 22^{\prime} 53.07^{\prime \prime}$ & 70 & Karunarathna et al., 2015 \\
\hline 23 & Nanperial estate & Ratnapura & & $6^{\circ} 45^{\prime} 42.01^{\prime \prime}$ & $80^{\circ} 47^{\prime} 25.72^{\prime \prime}$ & 1380 & Karunarathna et al., 2015 \\
\hline 24 & Belihuloya & Ratnapura & & $6^{\circ} 42^{\prime} 37.01^{\prime \prime}$ & $80^{\circ} 47^{\prime} 12.08^{\prime \prime}$ & 609 & Karunarathna et al., 2015 \\
\hline 25 & Mungasthenna & Ratnapura & & $6^{\circ} 41^{\prime} 44.03^{\prime \prime}$ & $80^{\circ} 47^{\prime} 09.09^{\prime \prime}$ & 534 & Karunarathna et al., 2015 \\
\hline 26 & Matugama & Kalutara & & $6^{\circ} 31^{\prime} 15.31^{\prime \prime}$ & $80^{\circ} 07^{\prime} 23.00^{\prime \prime}$ & 80 & Karunarathna et al., 2015 \\
\hline 27 & Panadura & Kalutara & & $6^{\circ} 43^{\prime} 06.01^{\prime \prime}$ & $79^{\circ} 54^{\prime} 33.71^{\prime \prime}$ & 12 & Karunarathna et al., 2015 \\
\hline 28 & Yagirala & Kalutara & & $6^{\circ} 22^{\prime} 38.63^{\prime \prime}$ & $80^{\circ} 10^{\prime} 15.97^{\prime \prime}$ & 120 & Karunarathna et al., 2015 \\
\hline 29 & Kalugala & Kalutara & & $6^{\circ} 27^{\prime} 55.83^{\prime \prime}$ & $80^{\circ} 14^{\prime} 41.09^{\prime \prime}$ & 140 & Karunarathna et al., 2015 \\
\hline 30 & Nawalapitiya & Kandy & & $7^{\circ} 03^{\prime} 20.16^{\prime \prime}$ & $80^{\circ} 31^{\prime} 29.09^{\prime \prime}$ & 650 & Karunarathna et al., 2015 \\
\hline 31 & Sinharaja & Ratnapura/Kalutara & & $6^{\circ} 24^{\prime} 36.60^{\prime \prime}$ & $80^{\circ} 22^{\prime} 50.18^{\prime \prime}$ & 360 & Karunarathna et al., 2015 \\
\hline 32 & Telwatta & Galle & & $6^{\circ} 10^{\prime} 24.04 "$ & $80^{\circ} 05^{\prime} 26.61^{\prime \prime}$ & 12 & Karunarathna et al., 2015 \\
\hline 33 & Koslanda & Monaragala & & $6^{\circ} 44^{\prime} 32.99^{\prime \prime}$ & $81^{\circ} 01^{\prime} 12.18^{\prime \prime}$ & 700 & Karunarathna et al., 2015 \\
\hline 34 & Ohiya & Badulla & & $6^{\circ} 49^{\prime} 04.00^{\prime \prime}$ & $80^{\circ} 50^{\prime} 38.56^{\prime \prime}$ & 1600 & Karunarathna et al., 2015 \\
\hline 35 & Maskeliya & Nuwara-Eliya & & $6^{\circ} 50^{\prime} 36.35^{\prime \prime}$ & $80^{\circ} 34^{\prime} 49.66^{\prime \prime}$ & 1300 & Karunarathna et al., 2015 \\
\hline 36 & Nortonbrige & Nuwara-Eliya & & $6^{\circ} 53^{\prime} 52.10^{\prime \prime}$ & $80^{\circ} 31^{\prime} 08.24^{\prime \prime}$ & 1100 & Karunarathna et al., 2015 \\
\hline
\end{tabular}



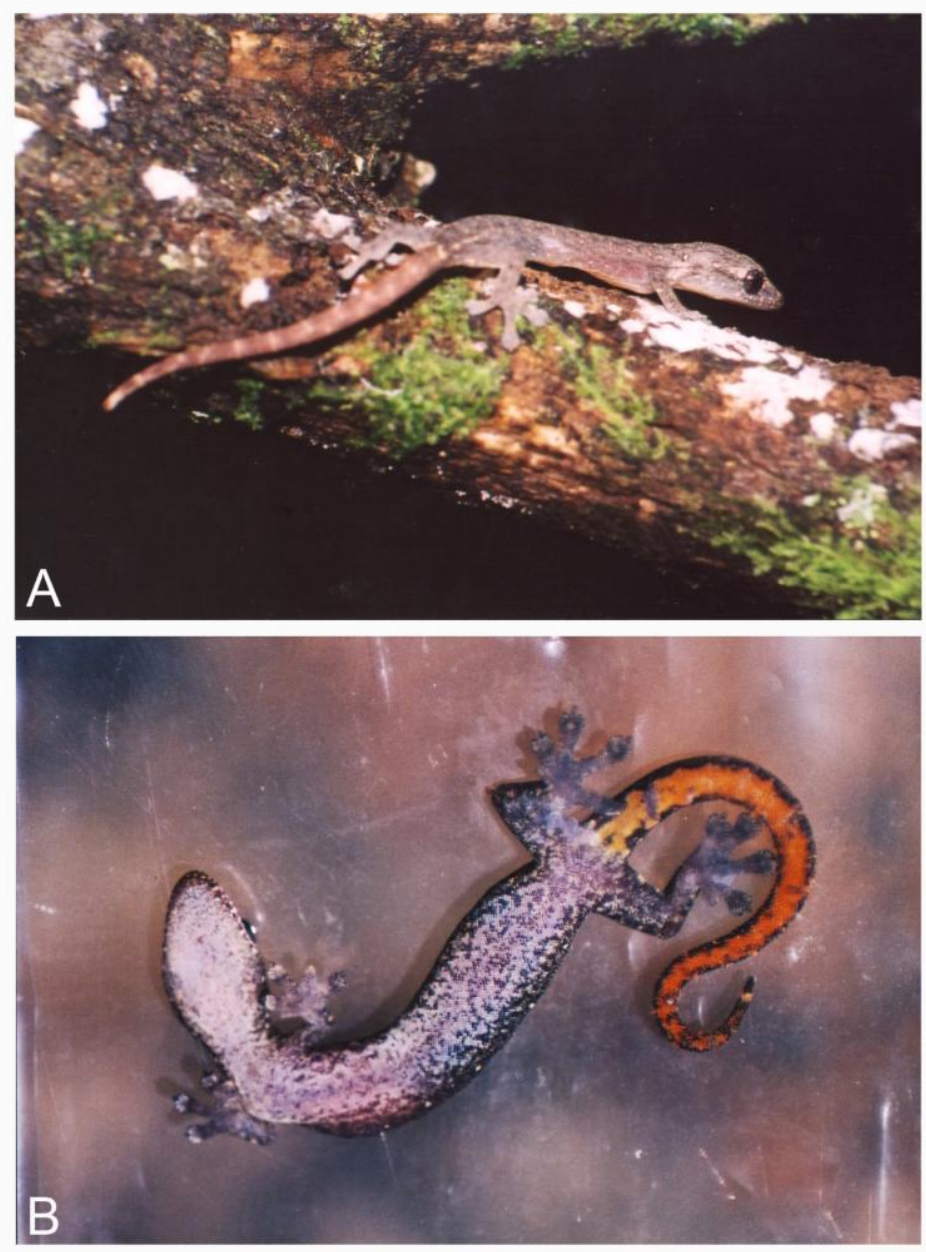

Figure 2: A, B: Juveniles of Hemiphyllodactylus typus from Morankanda Mukalana (loc. 18). The black caecum characteristic mainly for unisexual species is visible (2B).

\section{Morankanda Mukalana, Elpitiya, (location 18)}

The locality is a secondary forest, located in Indigahawila in Kahaduwa, Elpitiya (Galle District: Southern Province). Habitat of H. typus was anthropogenic and mostly surrounded with plant species such as Camellia sinensis, Cocos nucifera, Mangifera indica, Piper nigrum, Garcinia mangostana and Musa paradisiaca. During November 2004 to December 2009, a total of 15 observations were made in this site. These observed specimens were three new born, three juveniles and nine adults or subadults (31$41 \mathrm{~mm} \mathrm{SVL}$ ).

\section{Godahena, Ambalangoda (location 19)}

This site is located on the eastern boundary of Madampa Lake along the southwestern coastline of Sri Lanka, next to southern boundary of the RAMSAR wetland "Maduganga" Lagoon, Galle District. The vegetation is comprised mainly of mangroves with species including, Bruguiera sexangula, Sonneratia caseolaris and Nypa fruticans. From April 2009 to August 2010 only three specimens of $H$. typus were observed (two adults: $40.1 \mathrm{~mm}, 37.2 \mathrm{~mm}$ SVL and one juvenile).

\section{Pinnawala Elephant Orphanage (location 20)}

Pinnawala is located in a rural area, $13 \mathrm{~km}$ northeast of Kegalle town in the Sabaragamuwa Province. In November 2008, a single H. typus adult ( $3.8 \mathrm{~mm} \mathrm{SVL}$ ) was recorded inside a local building. It is an abandoned building surrounded by vegetation including Mangifera indica.

\section{Kesbewa (location 21)}

Two specimens were recorded in Kesbewa. The first specimen was recorded in October 2007, a single adult (36.2 $\mathrm{mm} \mathrm{SVL}$ ). This specimen was observed in nursery plants, which transported from location 18 (Morankanda-Mukalaana) in the same day. Thus, we assumed that the particular adult specimen was an accidental 
introduction to Kesbewa site. However, the second specimen recorded in August 2008 was a juvenile of $H$. typus.

\section{DISCUSSION}

Initial records of $H$. typus from Sri Lanka appeared in Boulenger's (1885) classification referred as the Beddome's collection (holotype BMNH 74.4.29.1326, location given as Gampola, Ceylon; see Table 1) as Lepidodactylus ceylonensis (synonym) on Catalogue of the Lizards in the British Museum (CLBM) (see also Boulenger, 1890). Subsequently Stejneger (1899) corrected the genus name as a $H$. ceylonensis and stated nomenclature as $H$. ceylonensis (see Werner, 1913; Zug, 2010). Later Smith (1935) listed it as a subspecies $H$. typus. Populations from Sri Lanka are currently designated as $H$. typus because the morphology of the holotype (BMNH 74.4.29.1326) was confirmed to be of this species. The situation in Sri Lanka is, however, more complicated due to historical evidence of unisexual and bisexual specimens and different morphology between populations (see below and Batuwita \& Alagiyawadu, 2004; Zug, 2010).

Hemiphyllodactylus typus is uncommon or scattered in many countries where it is been recorded (Zug, 2010; Grismer, 2011; Fisher et al., 2013). Based on present observations and available literature, the recorded sympatric geckoes were listed in Table 2. Hemiphyllodactylus typus recorded in number of different types of habitats in Sri Lanka (mangrove, plantations, primary and secondary forests, and anthropogenic habitats). Some of these records come from an elevation of above $1,000 \mathrm{~m}$ (Table 1). Observed pattern suggests that fragmented populations on the island. Most of observed sites were located in the southwestern part of the island, especially in coastal regions and central hills.

The current considered pattern of $H$. typus distribution, can be separated into two subpopulations, one is covers south-west lowlands with coastal plains and the other is central hills above the $1000 \mathrm{~m}$. The theoretical explanation for this two separated populations will be explored further.

However, (i) the slightly disjunctive pattern of distribution of this species in Sri Lanka (Figure 1), (ii) historical records of existence of both unisexual and bisexual populations (Zug, 2010) and (iii) morphological differentiation between lowland and central hills populations (Batuwita \& Alagiyawadu, 2004; Zug, 2010), we can suggest that populations of Hemiphyllodactylus on the island can be formed by two species; unisexual $H$. typus morph type and bisexual, presumably classified as $H$. aurantiacus morph type distributed also in southern and eastern India (Maqsood-Javed et al., 2010; Zug, 2010). On the other hand, we cannot exclude the fact that the latter is a new undescribed $\quad$ species (Zug, 2010).

Table 2: Syntopic species of family Gekkonidae recorded on some of Hemiphyllodactylus typus localities $(*=$ endemic species): $\mathrm{Gm}=$ Gehyra mutilata $; \mathrm{Hp}=$ Hemidactylus parvimaculatus $; \mathrm{Hf}=$ Hemidactylus frenatus; $\mathrm{Hd}=$ Hemidactylus depressus $* \mathrm{Ll}=$ Lepidodactylus lugubris; $\mathrm{Cs}=$ Cnemaspis silvula $* \mathrm{Cm}=$ Cnemaspis molligodai $*$; $\mathrm{GEt}=$ Geckoella triedrus $*$ PFR= Proposed Forest Reserve; $+=$ presence (see references in Table 1 ).

\begin{tabular}{|c|c|c|c|c|c|c|c|c|}
\hline $\begin{array}{l}\text { Location } \\
\text { No. }\end{array}$ & Location & Gm & Hp & Hf & Hd & $\mathbf{L l}$ & Cs & $\mathrm{Cm}$ \\
\hline 9 & Pitiwela & + & + & + & & & & \\
\hline 11 & Aluthgama & + & + & + & & + & & \\
\hline 12 & Pussellawa & + & + & + & & & & \\
\hline 14 & Penideniya & + & + & + & + & & & \\
\hline 16 & Kukulugala PFR & + & + & + & + & + & + & + \\
\hline 17 & Beraliya-Mukalana PFR & + & + & + & + & + & + & + \\
\hline 18 & Morankanda-Mukalana & + & + & + & & + & + & + \\
\hline 19 & Godahena Sanctuary & + & + & + & + & + & & \\
\hline 20 & Pinnawala & + & + & + & & & & \\
\hline 21 & Kesbawa & + & + & + & & + & & \\
\hline
\end{tabular}


The status of this genus in Sri Lanka can be confirmed through a widespread sampling and molecular/chromosomal evaluation. At present, the taxonomic status of the Sri Lankan bisexual population is indecipherable owing to paucity of data. Both morphotypes (presumably equal to $H$. typus and $H$. aurantiacus) are members of very diverse typus genetic group (mitochondrial ND2 marker; Grismer et al., 2013) and according to this phylogenetic hypothesis both fall into different clades of this group. In accordance with this hypothesis and with current distribution of the species (and colonization ability of $H$. typus) we can speculatively discuss that the origin of the one (bisexual) morphotype is natural $(H$. aurantiacus) while the second (unisexual) is the result of human-mediated introduction on the island (most of the current records come from the vicinity of main ports of the island, i.e. Colombo and Galle; Figure 1).

In general, very little information is known about the origin of parthenogenetic species in Sri Lanka (see Jayaneththi et al., 2015 for Lepidodactylus lugubris), and molecular investigation could uncover the answer. Geckoes are one of the top ten most successful introduced animal group in the world (Bomford et al., 2005) and parthenogenetic unisexual species are a wellknown example for that (see Zug, 2010; Daza et al., 2012). Considering the very dense maritime transportation in Sri Lanka (Indian Ocean) since the colonial period in the last 200 years, it is possible that $H$. typus naturalised in Sri Lanka after the colonial era. This hypothesis supports the occurrence of this species in Mascarene, Andaman and Nicobar Islands of the Indian Ocean where it is also a non-native (see Bour \& Moutou, 1982; Das, 1999; Lever, 2003; Chandramouli, et al., 2012). A similar phenomenon is supposed for L. lugubris in Sri Lanka (Jayaneththi et al., 2015). We are focusing further studies in par with Zug's (2010) original hypothesis, which states that the entire distribution of $H$. typus instigates from humanmediated transport (ships), possibly during the last two centuries. Further studies on these species will continue to evaluate dispersal events of H. typus and L. lugubris in Sri Lanka.

\section{ACKNOWLEDGEMENTS}

We would like to express gratitude to A. Rashintha, B. Holloway, M. Abhishek, P. Jayawardena for their assistance. Thanks are also extended to J. Christophoryová for her suggestions on the manuscript.

\section{REFERENCES}

Batuwita, S. (2000). Lizards of Mount Gannoruwa. Loris. 22 (3): 13-15.

Batuwita, S. and Bahir, M.M. (2005). Description of five new species of Cyrtodactylus (Reptilia: Gekkonidae) from Sri Lanka. In: Yeo, D.C.J., P. K.L. Ng and R. Pethiyagoda (eds.). Contributions to biodiversity exploration and research in Sri Lanka. The Raffles Bulletin of Zoology. Supplement No. 12: 351-380.

Batuwita, S. and Alagiawadu, I. (2004). Some observations on Hemiphyllodactylus typus Bleeker, 1860: Sri Lanka (Squamata: Gekkonidae). Lyriocephalus Special Issue 5 (1 \& 2): 146-149.

Bomford, M., Kraus, F., Braysher, M., Walter, L. and Brown, L. (2005). Risk assessment model for the import and keeping of exotic reptiles and amphibians. A report produced by the Bureau of Rural Sciences for The Department of Environment and Heritage - Commonwealth of Australia, Canberra, 110.

Boulenger, G.A. (1890). The Fauna of British India, Including Ceylon and Burma. Reptilia and Batrachia. Taylor \& Francis, London, xviii, 541.

Boulenger, G.A. (1885). Catalogue of the Lizards in the British Museum (Nat. Hist.) I. Geckonidae, Eublepharidae, Uroplatidae, Pygopodidae, Agamidae. London: 450.

Bour, R. and Moutou, F. (1982). Reptiles et amphibiens de l'île de La Réunion. Info Nature. 19: $121-156$.

Chandramouli, S.R., Harikrishnan, S. and Vasudevan, K. (2012). Record of the Indo-Pacific Slender Gecko Hemiphyllodactylus typus (Squamata: Sauria: Gekkonidae) from the Andaman Islands, India. Journal of Threatened Taxa. 4(4): 25362538.

Deraniyagala, P.E.P. (1953). A colored atlas of some vertebrates from Ceylon; volume two, Tetrapod Reptilia, Ceylon National museums, Colombo. 99.

Das, I. (1999). Biogeography of the amphibians and reptiles of the Andaman and NicobarIslands, India, pp. 43-77. In: Ota, H. (ed). Tropical Island herpetofauna. Origin, Current Diversity and Current Status. Elsevier Science BV, Amsterdam, The Netherlands, 353.

Daza, J.D., Travers, S.L. and Bauer, A.M. (2012). New records of the mourning gecko Lepidodactylus lugubris (Duméril and Bibron, 1836) (Squamata: Gekkonidae) from Colombia. CheckList. 8: 164-167.

De Silva, A., Bauer, A.M., Austin, C.C., Goonewardene, S., Drake, J., De Silva, P., Aberathna, M.G.T.H., Dassanayaka, T., Samarawickrama, G.S., Dasanayaka . R.D.C.S.K., 
Amarakoon, A.M.R.K. and Goonasekera, M.M. (2005). The diversity of the Knuckles ecosystem with special reference to its herpetofauna; Lyriocephalus Special issue. 6 (1 \& 2); 13-34.

Fisher, R.N., Uili, M., Enoka, F. and Zug, G.R. (2013). Clarifying the distributional records for Hemiphyllodactylus typus (Bleeker, 1860) from Central Oceania. Herpetology Notes. 6: 247-250.

Goonewardene, S., Drake, J. and De Silva, A. (2006). The Herpetofauna of the Knuckles Range. Project Knuckles 2004 and 2005: University of Edinburgh Research Expedition. Amphibia and Reptile Research Organisation of Sri Lanka (ARROS) 209.

Grismer, L.L. (2011). Lizards of the Peninsular Malaysia, Singapore and their Adjacent Archipelagos. Edition Chimaira, Frankfurt am Main, Germany. 728.

Hijmans, R.J., Guarino, L., Mathur, P., Jarvis, A., Rojas, E., Cruz, M. and Barrantes, I., DIVA-GIS Version 7.5 Manual 2012. www.diva-gis.org.

Holden, M., Girard, F. and Ineich, I. (2014). Eggs and hatchlings of Hemiphyllodactylus typus Bleeker, 1860 (Gekkonidae) on a small islet in New Caledonia. Herpetology Notes. 7: 509-513

Jayaneththi, H.B., Madurapperuma, P.L., Velauthem, A.V., Balasuryia, N.H. and Jablonski, D. (2015). Bewertung der Verbreitung des Schuppen finger geckos Lepidodactylus lugubris (Duméril \& Bibron, 1836) in Sri Lanka (Distributional assessment on the Common Smooth-scaled gecko, Lepidodactylus lugubris (Dumeril \& Bibron, 1836), in Sri Lanka). Sauria. 37(2): 17-26.

Jayaneththi, H.B. (2015). Vertebrate fauna of Morankanda-Mukalana secondary forest patch in Sri Lanka: A checklist reported from 2004-2008 survey. Ruhuna Journal of Science. Vol 6: 21-41.

Karunarathna, D.M.S.S. and Amarasinghe, A.A.T. (2010). Reptile diversity of a fragmented lowland rainforest patch in Kukulugala, Ratnapura district, Sri Lanka. Taprobanica. 2: 86-94+1pl.

Karunarathna, D.M.S.S. and Amarasinghe, A.A.T. (2012). Reptile diversity in Beraliya Mukalana proposed forest reserve, Galle District, Sri Lanka. Taprobanica. 4: 20-26+pl.

Karunarathna, D.M.S.S., Surasinghe, T.D., Madawala, M.B., Wellappulli-Arachchi, S.M., Kandambi H.K.D., Kusuminda, T.G.T., Priyadarshana, T.M.T.S. and Perera, B.N.H. (2015). Distribution, natural history and the conservation status of Hemiphyllodactylus typus and Lepidodactylus lugubris (Reptilia: Gekkonidae) in Sri Lanka. Sri Lanka Naturalist. 8 (1-2), 13-22.

Lever, C. (2003). Naturalized Reptiles and Amphibians of the World. Oxford University Press, Inc., New York. 344.

Manamendra-Arachchi, K.N. (1997). Gecko!, Sri Lanka Nature, WHT Publication. 1(1): 45-54.

Manamendra-Arachchi, K., Batuwita, S. and Pethiyagoda, R. (2007). A taxonomical revision of the Sri Lankan day-geckos (Reptilia: Gekkonidae: Cnemaspis), with description of new species from Sri Lanka and India. Zeylanica. 7(1): 9-122.

Maqsood-Javed, S. M., Thulsi-Rao, K., Srinivasulu, C., Tampal, F. (2010). Distribution of Hemiphyllodactylus aurantiacus (Beddome, 1870) (Reptilia: Gekkonidae) in Andhra Pradesh, India. Journal of Threatened Taxa. 2: 639-643.

Ministry of Environment National Redlist (MENR). 2012. The National Red List 2012 of Sri Lanka; Conservation Status of the Fauna and Flora. Ministry of Environment, Colombo, Sri Lanka. 476.

Smith, M.A. (1935). The fauna of British India including Ceylon and Burma. Reptilia and Amphibia, 2, Sauria, Taylor and Francis, London ix +440 .

Somaweera, R., Somaweera, N. (2009). Lizards of Sri Lanka: A colour guide with field keys. Edition Chimaira, Frankfurt/Main, Germany, 303.

Somaweera, R., Karunarathna, S., Ukuwela, K. (2001). The Kandyan Tetrapod Herps, Loris; 22, (6). Journal of the Wildlife and Nature Protection Society of Sri Lanka. 3-10.

Stejneger, L. (1899). The Land Reptiles of the Hawaiian Islands. Proceedings of the United States National Museum. 21: 783-813.

Werner, F. (1913). Neueoderseltene Reptilien und Frösche des Naturhistorischen Museums in Hamburg. Reptilien der Ostafrika-Expedition der Hamburger Geographischen Gesellschaft 1911/12. Leiter: Dr. E. Obst. Reptilien und Amphibien von Formosa. Jb. Hamb. wiss. Anst., 30 [1912], 2. Beiheft: 1-39, 40-45, 45-51.

Zug, G.R. (2010). Speciation and Dispersal in a Low Diversity Taxon: The Slender Geckos Hemiphyllodactylus (Reptilia, Gekkonidae). Smithsonian Contributions to Zoology. 631: 1-70. 